\title{
Études/Inuit/Studies
}

\section{Uelen hunters and artists}

\section{Les chasseurs et artistes de Uelen}

\section{Mikhail M. Bronshtein}

Volume 31, numéro 1-2, 2007

\section{Tchoukotka}

Chukotka

URI : https://id.erudit.org/iderudit/019716ar

DOI : https://doi.org/10.7202/019716ar

Aller au sommaire du numéro

\section{Éditeur(s)}

Association Inuksiutiit Katimajiit Inc.

Centre interuniversitaire d'études et de recherches autochtones (CIÉRA)

\section{ISSN}

0701-1008 (imprimé)

1708-5268 (numérique)

Découvrir la revue

\section{Citer cet article}

Bronshtein, M. M. (2007). Uelen hunters and artists. Études/Inuit/Studies, 31(1-2), 83-101. https://doi.org/10.7202/019716ar

\section{Résumé de l'article}

Uelen est un village habité par des résidents tchouktches maritimes et yupik, qui non seulement chassent les mammifères marins mais aussi sculptent leur ivoire. Des fouilles archéologiques entreprises à Uelen ont démontré que l'ivoire y a été sculpté depuis au moins le début de notre ère. Quand les baleiniers et les marchands vinrent à Uelen au 19e siècle, la sculpture traditionnelle de l'ivoire se transforma en artisanat populaire. En 1931, les résidents d' Uelen furent les premiers à ouvrir un atelier de sculpture de l'ivoire en Tchouktoka. Au milieu des années 1930, ils bénéficièrent de l'aide de l'artiste et critique d'art russe Alexander Gorbunkov qui les encouragea à développer leur propre potentiel artistique. À la fin des années 1930, les sculpteurs avaient acquis un style particulier basé sur leur connaissance des coutumes des chasseurs de l'Arctique, les images expressives des animaux polaires et la beauté naturelle de l'ivoire de morse. La participation de nombreux résidents d'Uelen à la sculpture sur ivoire fut la raison principale de sa préservation durant la Seconde Guerre Mondiale et la dure période de l'après-guerre. De nouvelles tendances, incluant des thèmes humains et folkloriques sont apparus dans les années 1950 à 1970 avec aussi des représentations de chasse traditionnelle. Durant les années 1980 et 1990, les artistes inclurent dans leur art certains motifs d'ornements préhistoriques. Si de nombreux artistes de la Tchoukotka recourent à de nouveaux modes d'expression dans les années 2000, les sculpteurs d'Uelen sont en général plus traditionnels. Pour eux, la sculpture est devenue un symbole de la culture ancestrale en voie de disparition.
Tous droits réservés @ La revue Études/Inuit/Studies, 2007
Ce document est protégé par la loi sur le droit d'auteur. L’utilisation des services d'Érudit (y compris la reproduction) est assujettie à sa politique d'utilisation que vous pouvez consulter en ligne.

https://apropos.erudit.org/fr/usagers/politique-dutilisation/ 


\title{
Uelen hunters and artists
}

\author{
Mikhail M. Bronshtein*
}

\section{Résumé: Les chasseurs et artistes de Uelen}

Uelen est un village habité par des résidents tchouktches maritimes et yupik, qui non seulement chassent les mammifères marins mais aussi sculptent leur ivoire. Des fouilles archéologiques entreprises à Uelen ont démontré que l'ivoire y a été sculpté depuis au moins le début de notre ère. Quand les baleiniers et les marchands vinrent à Uelen au 19e siècle, la sculpture traditionnelle de l'ivoire se transforma en artisanat populaire. En 1931, les résidents d' Uelen furent les premiers à ouvrir un atelier de sculpture de l'ivoire en Tchouktoka. Au milieu des années 1930, ils bénéficièrent de l'aide de l'artiste et critique d'art russe Alexander Gorbunkov qui les encouragea à développer leur propre potentiel artistique. À la fin des années 1930, les sculpteurs avaient acquis un style particulier basé sur leur connaissance des coutumes des chasseurs de l'Arctique, les images expressives des animaux polaires et la beauté naturelle de l'ivoire de morse. La participation de nombreux résidents d'Uelen à la sculpture sur ivoire fut la raison principale de sa préservation durant la Seconde Guerre Mondiale et la dure période de l'après-guerre. De nouvelles tendances, incluant des thèmes humains et folkloriques sont apparus dans les années 1950 à 1970 avec aussi des représentations de chasse traditionnelle. Durant les années 1980 et 1990 , les artistes inclurent dans leur art certains motifs d'ornements préhistoriques. Si de nombreux artistes de la Tchoukotka recourent à de nouveaux modes d'expression dans les années 2000 , les sculpteurs d'Uelen sont en général plus traditionnels. Pour eux, la sculpture est devenue un symbole de la culture ancestrale en voie de disparition.

\section{Abstract: Uelen hunters and artists}

Uelen is a settlement inhabited by coastal Chukchi and Yupik people who do not only hunt sea animals but also carve their ivory. Archaeological excavations in Uelen testify that ivory carving has existed there at least since the beginning of our era. When whale hunters and traders came in Uelen in the 19th century, traditional ivory carving turned into an ethnic handicraft. In 1931, Uelen residents were the first to open an ivory carving workshop in Chukotka. In the mid1930 s, they benefited from the valuable help of the Russian artist and art critic Alexander Gorbunkov, who encouraged them to develop their own artistic potential. By the end of the 1930s, Uelen carvers and engravers had acquired their particular artistic style based on their deep knowledge of the Arctic hunters' customs, expressive images of polar animals, and the natural beauty of walrus tusk. The involvement of a large number of Uelen inhabitants in ivory carving was the main reason for its preservation during the Second World War and the difficult aftermath. New tendencies, including human and folklore themes, emerged in the 1950s-1970s alongside traditional hunting depictions. In the 1980s and 1990s, Uelen artists included in their art some patterns from prehistoric ornaments. While many Chukotka artists are using new creative ways in the $2000 \mathrm{~s}$, Uelen carvers in general keep closer to tradition. For them, ivory carving has become a symbol of the vanishing culture of their ancestors. 


\section{Introduction}

Uelen is located in the northeastern corner of the Chukotka Peninsula, precisely where the Bering Strait meets the Arctic Ocean. It has 800 inhabitants, mainly coastal Chukchi and a few Yupik families. Like other coastal people in Chukotka, Uelen residents hunt sea mammals, fish, and gather berries and roots in the tundra. They have, however, one specific feature since many of them are descendants of carvers and engravers of walrus tusks (Figure 1). Archaeological data show that ivory carvings and engravings were present in Uelen long before the opening of an ivory carving workshop in 1931. Numerous artefacts made from walrus tusks have been excavated, and depending on their stylistic characteristics (e.g., harpoon heads, stabilisers and foreshafts; ritual carvings; and ornaments), they can be dated from as early as the prehistoric Eskimo cultures of the first millennium A.D., to the first half of the second millennium A.D., as well as to the protohistoric period of the 16th-18th centuries (Arutiunov and Sergeev 2006) ${ }^{1}$.

During the second half of the 19th century, Uelen's long tradition of ivory carving got a new opportunity to grow. At that time, the coast of Chukotka, and especially Uelen (located in the narrowest part of the Bering Strait), was often visited by schooners of whalers and traders. Exotic products made from walrus tusk caught the visitors' attention. Hence, specially for them, local residents began to carve small figures of polar animals, pipes, hair-pins, and in that way, ivory carving became an ethnic handicraft in Chukotka. This transformation of traditional ivory carving into a popular handicraft coincided with yet another important cultural process, the arrival of the Chukchi with their language and culture, to the Yupik coastal territories. This process had started in the 17 th and 18 th centuries. As a result, a new culture emerged in many settlements of sea hunters which combined closely Yupik and Chukchi features. In my view, the Yupik ivory carving component played a significant role in this new culture due to the location of Uelen next to the large Yupik settlement of Naukan. The 19th century Uelen residents who considered themselves coastal Chukchi maintained very close (notably kinship) relations with the Naukan Yupik people.

Despite a significantly decreased presence of western whalers in the Bering Strait in the early 20th century, foreigners continued visiting Uelen, and thus ivory carving maintained its development. Besides figures of polar animals and utilitarian objects, Uelen carvers started to create graphic representations on whole walrus tusk, a new kind of exclusively decorative craft. In the 1920 s, Uelen ivory carving reached a new stage. Uelen residents were among the first in Chukotka to organise a seasonal ivory carving brigade and to start teaching ivory carving in the local school. Thus, when the Uelen ivory carving workshop opened in 1931, there were many local people already involved in carving. 


\section{The Uelen ivory carving workshop}

As Mitlyanskaya (1976: 49) explained, the initiator of the Uelen carving workshop was a local resident named Tegrynkeu. A dynamic and enterprising person, he had been a successful sea hunter, a sailor on an American schooner, and had worked in the Chukotka administration. Like most of the Uelen residents, he was good at carving, although not as good as his younger brother named Vukvutagin. Vukvutagin, who was in his early $30 \mathrm{~s}$ at that time, was remarkably skilled in crafting laconic yet surprisingly lively images of animals. Being a hunter and from a lineage of hunters, he had perfect knowledge about the anatomy and behaviour of Arctic animals. Therefore he was notably able to express in his images distinctive body features of walruses and polar bears in typical poses. Tegrynkeu offered Vukvutagin to bring together the most experienced Uelen carvers, some of whom had retired from sea mammal hunting. Tegrynkeu believed that these people would be able to work on crafting not only on seasonal but also on year-round basis.

In the very beginning, only three carvers started working at the workshop: Aie, Aromke, and Khal'mo, alongside with Vukvutagin who became director of the workshop (Figure 2). Each of these first Uelen professional artists had a style of his own. Aie, the eldest one (born in 1877, he was 15-20 years older than his colleagues), had carved miniature sculptures of walrus, bears, and seals. He had also represented some reindeer, as he was not only a sea mammal hunter but had also worked with the tundra reindeer herders. Aromke used to hunt but health problems kept him away from the sea; he was passionate about relief carving. Besides the volumetric figures of seals and walruses, he produced some group compositions in relief on cigarette cases as well as on whole walrus tusks. He transmitted his love for carving to his daughter Emkul' who eventually became one the most prominent engravers in Chukotka. Khal'mo, a brother of Vukvutagin and Tegrynkeu, was an experienced sea hunter and one of the strongest Uelen wrestlers. He mastered the untypical technique of openwork carving. He made small carving group compositions representing hunters eating on dog sleds (Bronshtein et al. 2002: 59, 93; Mitlyanskaya 1976: 50), and also cut small chains and brooches from walrus tusk.

In the mid-1930s, the number of Uelen artists significantly increased. Among the many talented carvers who joined the workshop were Khal'mo's sons Vukvol and Tukkai. In addition, there were some new engravers such as Leivun, Emkul' and Onno (the latter considered by many Uelen residents as a shaman) (Figure 3). Artists from the neighbouring settlements of Dezhnev and Naukan progressively intensified their visits to Uelen. This was the beginning of the transformation of the Uelen workshop into an important carving centre in Chukotka. The arrival of the Russian artist and art critic Alexander Gorbunkov in 1933 provoked further changes in the lives of the Uelen engravers and carvers. Sent to Chukotka by the central Soviet trading organisations that were interested in craft products made by northern peoples, Gorbunkov spent two years in Uelen. He managed to negotiate better salaries for the Uelen artists. He established especially good relationships with both the young and the most experienced artists, 


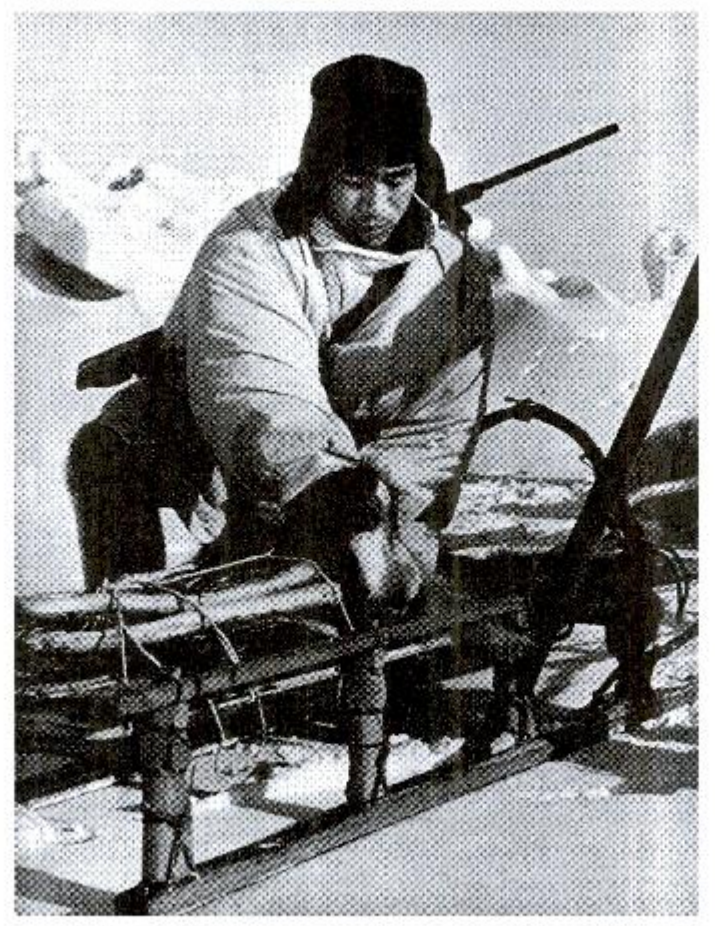

Figure 1. Ivan Seigutegin, skilled hunter, talented carver and engraver, the eldest Uelen artist, 1970s. Source: Bronshtein et al. (2002). Photo: Yury Muravin and Alexander Muravin.

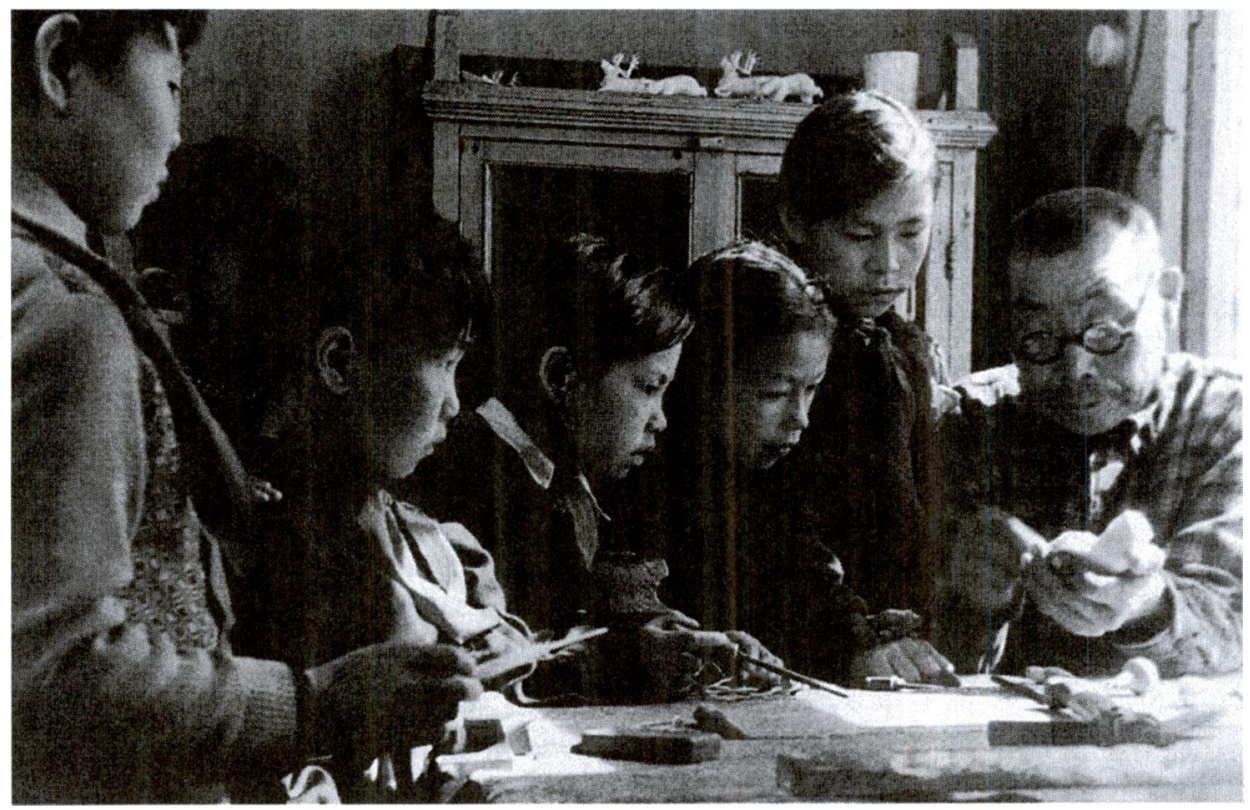

Figure 2. Uelen pupils visiting Vukvutagin, the first Director of the ivory carving workshop, 1960s. Source: Bronshtein et al. (2002). Photo: Yury Muravin and Alexander Muravin. 
although he faced some serious problems in the beginning. Here is a description of that situation:

Gorbunkov's interaction with the Native carvers in Chukotka was extremely complex. Accustomed to pleasing the tastes of their customers, outsiders who merely wished to take home an exotic souvenir from Chukotka, the Native artists at first displayed no aspiration toward creative independence. Instead, they sought instructions from Gorbunkov. An enormous responsibility thus lay on the shoulders of the professional artist $[\ldots]$. There was a danger of overwhelming the expression of the carver's individual creative potential with advice, of distancing the Native artists from their own ethnic tradition. On the other hand, a way needed to be found to create objects which would be marketable, and which could provide the Native carvers with stable income (Mitlyanskaya 1996: 70).

Looking for solutions, Gorbunkov decided to promote to the Uelen residents their own cultural traditions. He was insistently suggesting the use of "Native ornamental motifs used for fur and needle-work" to the ivory carvers working on cigarette cases, buttons, and writing accessories (ibid:: 72). As for the artists making graphical compositions on walrus tusk, he advised them to look for subjects in the Chukchi and Yupik traditional tales. Aware of the importance of the collective creative forms for the traditional art, Gorbunkov suggested to the Uelen artists to discuss their projects together. These discussions were often transformed in real performances, a kind of pantomimes that were helping the artists to find the most real and expressive images (ibid.: 74).

An important move in Gorbunkov's work was the creation of a collection that would represent the art of the peoples of Chukotka. That collection included art work by Uelen carvers and engravers, and was exhibited in 1937 in one of the largest Moscow art museums, the State Tretyakov Gallery. For many Russians at that time this exhibition became an original discovery of a unique cultural phenomenon, the art of the Chukchi and Yupik peoples.

Although some of Alexander Gorbunkov's views about Chukotka art work might nowadays be looked upon critically (e.g., he considered walrus tusk to be an unsuitable material for carving [ibid.: 71]), still the overall result of his involvement in Uelen is a positive one. In my view, it consisted in a special relationship between the visiting art critic and the local artists. His respectful attitude towards the original art traditions of the Chukchi and Yupik artists was at the basis of this relationship. Far from imposing western stereotypes of aesthetics to the Uelen artists, Gorbunkov's aim was to help them disclosing their own creative potential. In many aspects, his approach was in line with the theories of the leading Russian ethnologists in the first third of the 20th century according to which northern peoples had a "fine art culture" of their own (Mitlyanskaya 1976: 48).

Looking at the work of Uelen carvers and engravers, I find that by the end of the 1930s they had already developed that special art style that distinguishes Chukotka's best ivory carving pieces today. The basic features of this style are the thorough knowledge of the northern environment, a spontaneous worldview, the spiritual images 
of animals, and a fluid boundary between human and animals. Carvings of polar bears, seals and walruses made by Uelen masters in the 1930s still amaze by their realism and expressiveness. From the static images of the 19th century, Uelen carvers had gone forward to create surprisingly live and touching dynamic images of animals in complex stances. The themes of the walrus tusk engravings changed as well. Black-and-white images of separate hunting scenes gave way to multicolour compositions representing the life of the sea mammal hunters in all its variety (Figure 4). Many utilitarian objects made by Uelen artists in the second half of the 1930s got new features as well. Their decor became much more complex. Handles of caskets took the shape of polar animals and group scenes started to decorate the surface of some items (Figure 5).

How to explain this rise of Uelen carving craft in the 1930s? The answer to this question has been partly given by the activities of Alexander Gorbunkov, but there were other reasons as well. From the 1930s, the Soviet power started insistent policies towards the economic development of the Far North. Arctic explorers, sailors and pilots became heroes in the movies and newspapers. Reflected rays of their glory enhanced the visibility of the peoples of the North. Products made from walrus tusk became a fashion trend. Trading organisations started purchasing ivory carving works from Uelen to sell them in the large cities, especially Moscow and Leningrad (StPetersburg).

A great role in the onward development of the Chukchi and Yupik ivory carving art was played by yet another factor. In the scientific literature, it has been mentioned many times that at that stage of development, the traditional, magic, aspect of Chukotka ivory carvings and drawings tended to be outdated. Canonical representations lined up with the strict religious tradition and gave way to images defined by aesthetic principles (Bronshtein et al. 2002: 30; Mitlyanskaya 1976: 50). This new approach to ivory carving favoured the individual and original aspect in the works of the carvers and engravers. Uelen artists got more freedom to express their own personal images, experiences and styles. Accumulated during several decades, these latent changes found a favourable ground to flourish in the second half of the 1930s. Uelen artists' high creative potential, their involvement in the crafting process not only for material but also for creative reasons, highly contributed to the preservation of the carving crafts during the hard times of the next decade.

\section{The Second World War and the late 1940s}

Most of the negative changes in the life of Chukchi and Yupik peoples in the 1940s came with the Second World War. Uelen's links to the rest of the country sharply deteriorated so the market for ivory carving products practically disappeared. Furthermore, the talented master Vukvol died on the front (and Uelen's ivory carving workshop eventually took his name). But not only the war made the 1940s such a hard period for Chukotka artists, the unresponsiveness from the local power deprived them of rooms for teamwork. The same situation prevailed in Naukan while the carving workshop in Dezhnev, where talented artists had also been working with Alexander 
Gorbunkov in the 1930s, was definitely shut down. From 1945 to 1948, the authorities' attempt to help Chukotka artists completely failed. Hence, although a small company called "Uelenskii Promkombinat" was created in Uelen with the purpose to buy arts and craft, when it became more difficult to trade the latter, the officials' solution was to shut it down and to literally destroy Chukchi and Yupik art products.

It is difficult to understand why local authorities who had definitely supported the ivory carving workshop in its beginning suddenly withdrew their support and even worsened the artists' working conditions. I think that this ambiguous situation was defined by the communist political and economic system that was ruling Russia at that time. Soviet policies were heavily influenced by subjective factors such as leaders' personalities and their demagogical care of "people's well-being." While Soviet power had declared its official support to the Arctic peoples' culture, it had hardly done anything in that sense. More precisely, it had done it only when it was at its own advantage. In the 1930s, the first collective farms ("kolkhozes") appeared in the North and the creation of the ivory carving workshop in Uelen was seen by Chukotka's communist leaders as a step towards supporting the culture of Arctic peoples. At the same time, Soviet power lacked sustainable interest in the development of the traditional Chukchi and Yupik cultures (in fact, the basic values of those cultures did not always fit well with the ones advocated by the communists), therefore support for the ivory carving artists was carried out "off and on." A great deal of decisions depended on the particular official's subjective views and bias. For instance, the official was able to decide by himself to either raise artists' wages (as market relations were irrelevant in Soviet economy) or to worsen their situation by closing their teamwork premises.

Despite all the above mentioned challenges, Uelen ivory carving art kept developing during the Second World War and the also difficult post-war period. Thus, an important step was made regarding carving. While in the 1920s and 1930s carvers were creating mostly single compositions, in the 1940s they made many more - and bigger - group compositions. Especially successful were Armoke's works (Figure 6). Group compositions required a more complex design. The artist had to conceive the subject, chose the composition's settings, find each character's most convincing features, and express motion. A most remarkable feature of the group compositions was the insertion of drawings in the sculpture. The latter were carried out on massive plates of walrus tusks that served as support for the carving. The drawing of the subject was in dynamic relation with its composition. This enhanced the narrative and even "cinematographic" level of the group compositions. Creating single or group compositions, drawing on walrus tusks, utilitarian art objects, Uelen artists were keeping close to tradition, although the 1940s works of art were more influenced by their author's personal style than ever before. The artist's style was easy to recognise in the carving's composition, proportions, expression of motion, and the choice of colours for the drawings. 

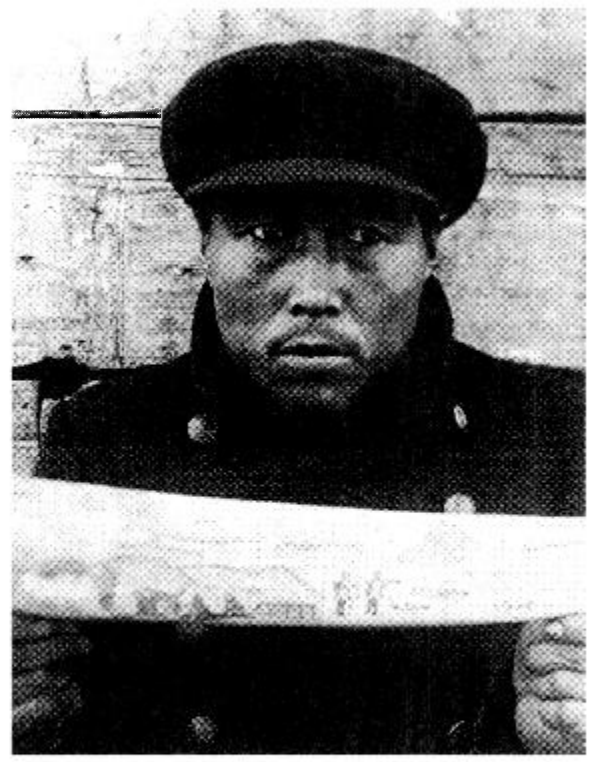

Figure. 3. Onno, carver and shaman in the 1930s. Source: Bronshtein et al. (2002).

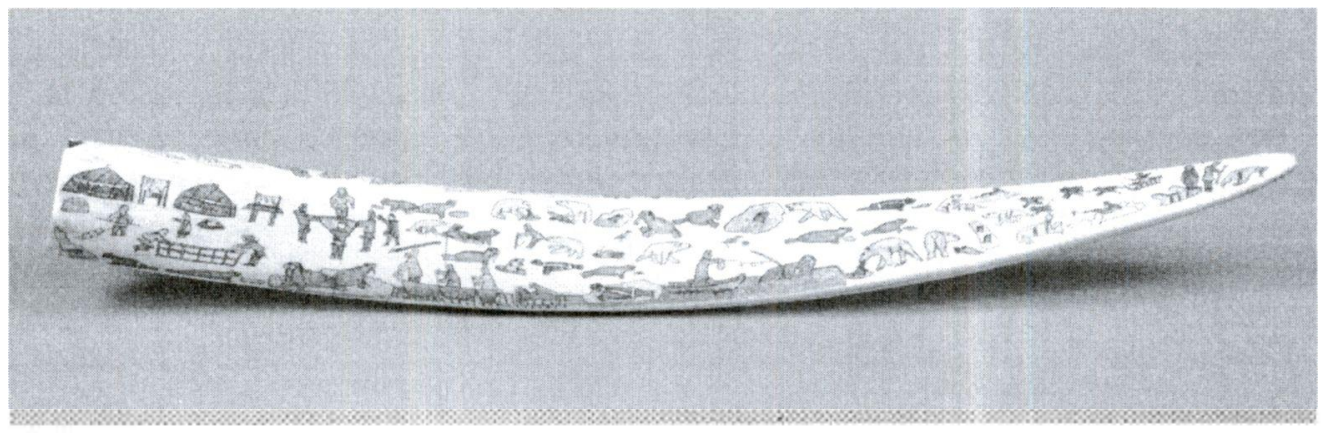

Figure 4. Engraved tusk of coastal Chukchi life by Leivun, 1930s. Source: Bronshtein and Shirokov (in press). Photo: Evgeny Zheltov.

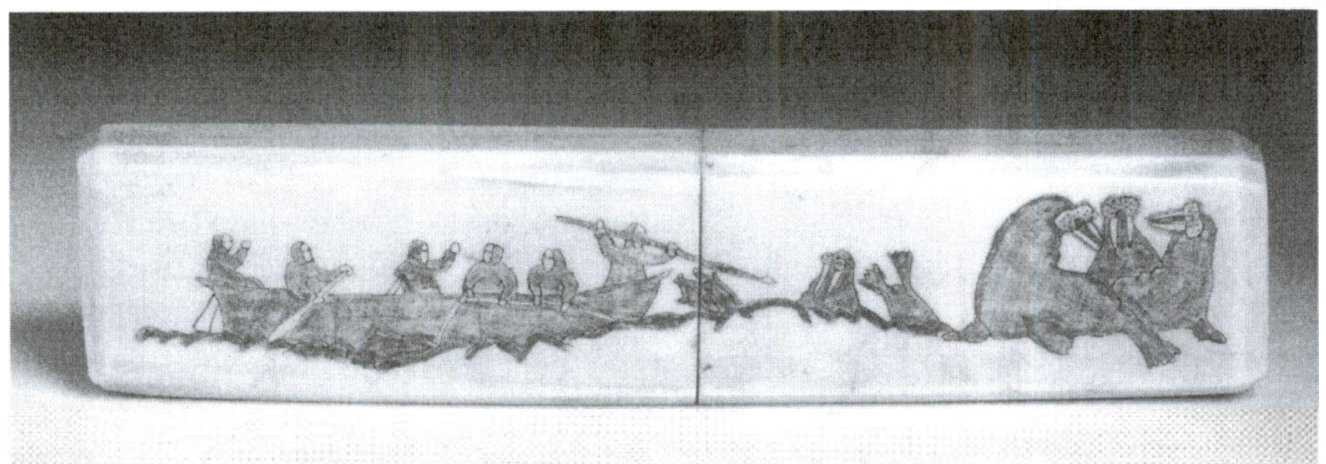

Figure 5. School pencil-box on a walrus tusk with engraving by Khukhutan,1930s. Source: Bronshtein and Shirokov (in press). Photo: Evgeny Zheltov. 


\section{The 1950s to 1970s}

The 1950s wrote a new page in the history of Uelen ivory carving. This was another difficult and contradictory period in the life of Russia's northerners. The Soviet government accelerated the "sovietisation" of Chukotka, a process that had begun in the 1930s with some extremely repressive measures towards the local population. In the post-war period, the restrictive border regime in the Bering Strait dramatically intensified. For Uelen and neighbouring residents, this meant restricted access to the sea. Hunters were not anymore allowed to hunt in the traditional places where their fathers and ancestors had hunted. Then, communities which had been living close to the border were forced to move. Thus Dezhnev and Naukan were closed by the State (Krupnik and Chlenov, this volume). Such measures sharply affected the traditional culture of the sea mammal hunters. As a consequence, the original Dezhnev and Naukan ivory carving styles that had developed in the 1930s and 1940s disappeared in the 1950s. On the other hand, this forced relocation of ivory carvers--such as the famous Yupik master Khukhutan - from smaller settlements to Uelen reinforced the position of its workshop as the major carving centre in Chukotka.

In the 1950s, the Uelen workshop was granted a new modern building, which furthermore increased its status. The artists' working conditions improved thanks to Igor Lavrov, a Moscow artist who managed the Uelen workshop from 1955 until 1958. He succeeded in convincing bureaucrats to recreate those pre-war conditions where artists could work in a common premise while discussing and following one another's work in progress. Collective work has always been essential for the Indigenous peoples of Chukotka. Therefore the resumption of the collective art forms in the 1950s had a positive impact on the development of the Uelen ivory carving craft. Two more factors, related to Lavrov's activities, were important for the rise of the Uelen craft in the mid20 th century. Firstly, acknowledging the need of social recognition for Arctic artists, he did everything possible to draw popular attention to the Uelen art from the big cities in central and Far-East Russia. Thanks to his efforts, in the second half of the 1950s, the best Uelen works reappeared in such art exhibitions as the ones in Magadan, Khabarovsk, Moscow and Leningrad (Saint-Petersburg). The second factor was the use of a new technology. Lavrov was among the first ones to suggest to Uelen artists the use of electric tools which greatly facilitated their work. It also attracted some young people to the workshop, as they were quicker to adapt to new means of ivory carving than the older masters.

Another undeniable merit of Lavrov was his support for Emkul' and other Uelen carvers who were directly inspired by Chukchi and Yupik folklore. Although the first compositions on ancient legends appeared in Uelen in the 1930s, they remained rare until the 1950s. Lavrov read to the artists some popular Chukotka tales collected by ethnographers, and wrote down stories that he had heard from Uelen residents (Mitlyanskaya 1976: 127; 1996: 73-74). By the second half of the 1950s, the folklore movement had become one of the cores of Chukchi and Yupik carving (Figure 7), Through his work on improving artists' working conditions, advertising their art production and supporting its local colour, Igor Lavrov followed the path of his 
predecessor Alexander Gorbunkov. Yet he took a much more active part in the very process of creation than Gorbunkov ever did. For instance, Lavrov encouraged Uelen artists to put more intensity and drama in their art. Hence, he suggested to the carvers to represent hunters spearing walrus, and herders beating off a wolf attack on a reindeer herd. Tamara Mitlyanskaya, who knew Lavrov very well, has described his work methods with the Uelen artists in the following way:

Understanding that the language of graphic arts was closer to the local carvers than speech itself, Lavrov made schemes or sketches of future sculptural compositions as they occurred to him. The native carver, in turn, would make his own corrections to the drawings, based on his knowledge of the local environment, and investing the composition with a sculptural form. Naturally, the carver's handling of the material and his ability to work in ivory brought new features to the sculptural composition, which departed from the image outlined in the original drawing, thus facilitating his individual expression (Mitlyanskaya 1996: 7374).

Such supervisory methods are difficult to assess without some ambiguity, since Lavrov was likely driven by his desire to make Uelen art more attractive to buyers by magnifying the exotic appeal of the North. Probably, Lavrov should have been more careful with his recommendations and not handing his own concepts to the Uelen masters. On the other hand, fight scenes had appeared in Chukotka's carvings yet before his arrival in Uelen. Hence, his emphasis on subjects with most intensive expression of their heroes' physical and mental strength was not in contradiction with the tradition.

One must take into account another significant detail. Uelen artists held their own rich and versatile creative experience. Therefore it is not excluded that that diversity, which one can find in their works on the opposition between human and animal, came directly from their own worldview. Addressing such themes, Uelen artists had often broken the proportions; hence hunters' figures decreased while animal ones increased. Deepening the contrast between the human and animal enhanced the opposing ways to represent characters. Thus humans were represented in rapid movement while walruses and seals kept still majestic poses. Another largely applied stylistic mean was to represent the human in full details, including facial expression and garments while the image of the animal was laconic and extremely simplified.

What lied behind such stylistics? Did Uelen artists from the 1950s intentionally adopt various creative ways in order to invest their work with additional worldview and philosophical meaning? Today it is hardly possible to give any firm answer to this question. But one can say more definitely that a bit later, in the 1960s and 1970s, new semantic components were already so apparent in the Uelen art that it is rather impossible not to see them. One can see those new features in the works of Kililoi and Lev Nikitin. Like many of their predecessors, both artists carved single compositions of polar animals, yet their walruses and seals acquired a distinctive humanistic and spiritual aspect. Thus animals appear not as "hunting objects" but as subjects that are notably similar to the humans. Such is Kililoi's "Walrus with her calf" where the 
mother lies on one side and carefully supports her baby by her flippers. Her pose is graceful, as a pose of a woman nursing her child. One can find similar warmth in Nikitin's sculpture "White-coat seals" representing two little seals who have touchingly nestled to each other (Figure 8).

This humanistic aspect that eventually became Uelen ivory carving's trademark led to a new representation of humans as well. In the 1970s, Uelen artists started representing ordinary Uelen inhabitants involved in their everyday activities. Small sculptures from either walrus tusk or whale bone (in the second half of the 20th century, Uelen carvers started using the latter quite often) represented Chukotka Indigenous peoples in a very realistic way, especially their faces, body proportions, clothes, characteristic movements and poses. As it often happens to truly original artworks, Uelen carvings have acquired, possibly beyond their authors' will, some remarkably new depth and symbolism.

Notable changes occurred in the walrus tusk carving in the 1960s and 1970s as the role of folklore themes progressively increased. "Transcendental girls," giants, and gigantic eagles became the new characters of the artists. Within only five years, from 1968 until 1973, more than 50 works based on Chukchi and Yupik legends were created in Uelen (Mitlyanskaya 1976: 166). Emkul' was the one who most often represented them. Since the 1950s, she had engraved a series of legend compositions on tusks, followed by younger artists such as Elena Ianku, Maia Gemauge, and Galina Tynatval' (Vukvutagin's daughter). Emkul's pupils from that period were her own daughter Lidia Teiutina along with Tatiana Pechetegina, another young artist. They are now the most famous artists in Uelen. This massive involvement of women in carving has left its mark in the history of popular art in Chukotka. Women have introduced new artistic means. They have given preference to smooth and lyrical tones, thin and refined lines. Having carefully worked even the smallest details, they have included both poetical and real images of the Arctic nature in their fairy-tales compositions. They have represented traditional Chukchi dwellings, hunters, and reindeer herders in traditional clothing. Although all female artists from the second half of the 20th century were strongly influenced by Emkul', each one had her own specific features. Researchers who have compared their works stress Tynatval's penchant for blue, yellow and orange tones; Elena Ianku's predilection for strict combinations of grey and brown; Maia Gemauge's tiny, fine lines; and Lidia Teiutina's large, vigorous drawing (ibid.: 160-161). These positive changes in the post-war carving art in Chukotka came along with some negative ones. According to Mitlyanskaya, in the 1960s Uelen artists ended up to a large extent torn off from their art tradition:

All prehistoric, traditional and/or art objects collected during ethnographic and archaeological surveys were typically removed from the area. Art products purchased from native artists normally became the property of state museums located far away $[\ldots \mid$. Thus $|\ldots|$ the native ivory carvers of Uelen craft shop were not familiar with the art of their predecessors, nor even with products created five or ten years prior. Therefore, they could not fully rely in their own work upon the very rich artistic legacy of Chukchi and Eskimo ivory carving (Mitlyanskaya 1996: 76). 


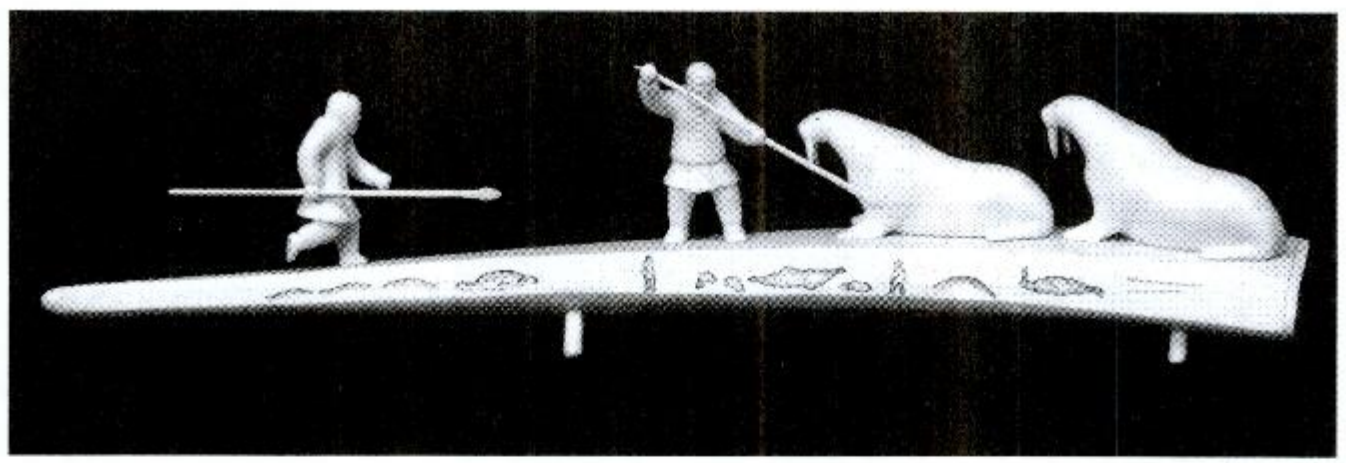

Figure 6. Walrus rookery hunting on walrus tusk carving and engraving by Aromke, 1942. Source: Bronshtein and Shirokov (in press). Photo: Evgeny Zheltov.

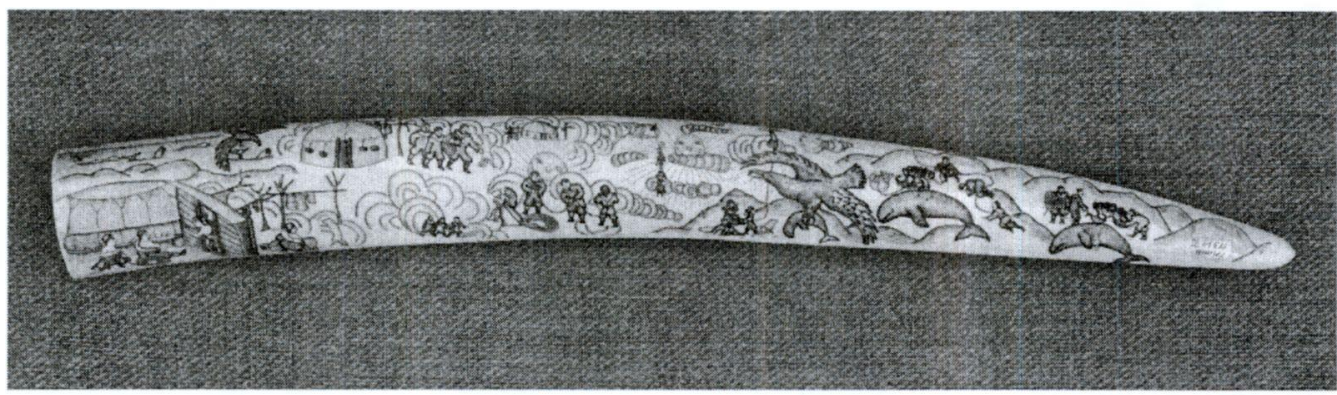

Figure 7. Walrus tusk engraving of the Chukchi tale "Man the Sun" by Emkul', 1956. Source: Bronshtein and Shirokov (in press). Photo: Evgeny Zheltov.

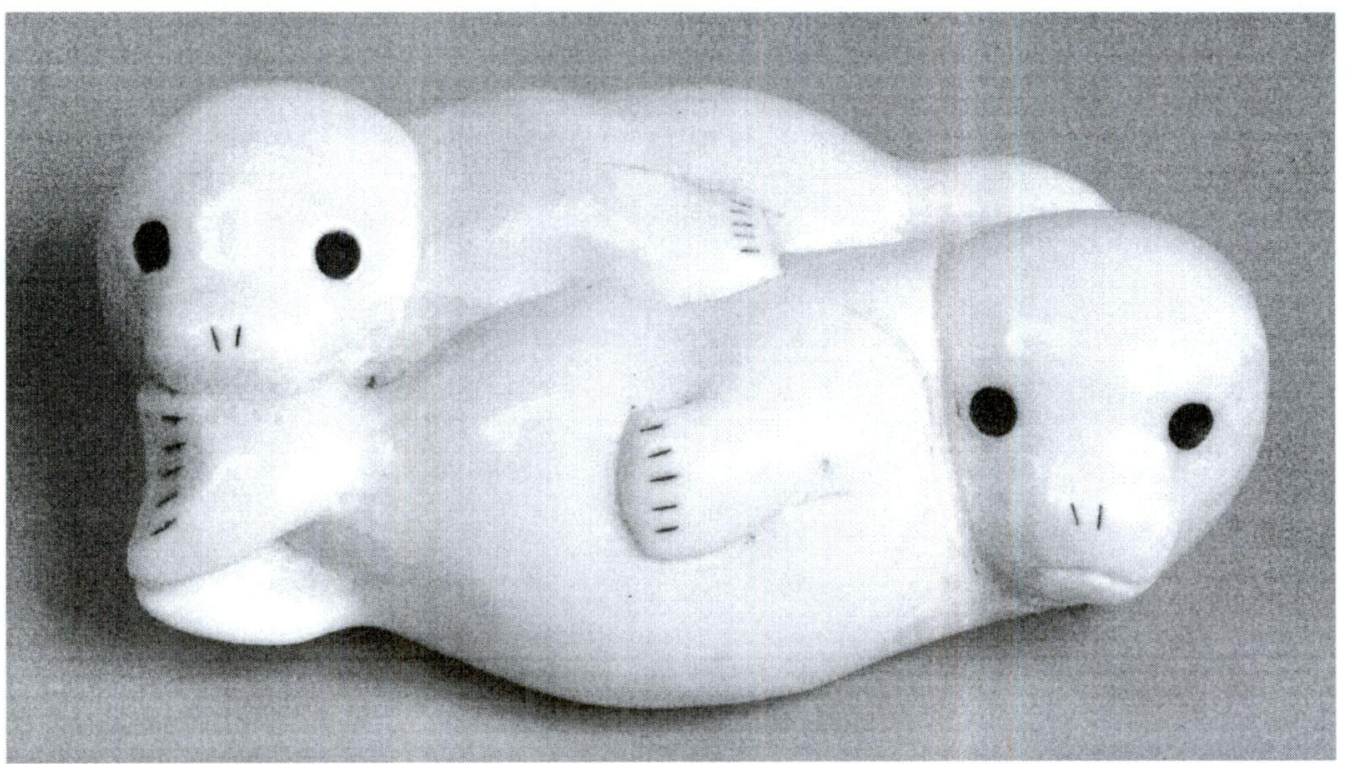

Figure 8. Walrus tusk carving of white coated seals by Lev Nikitin, early 1970s. Source: Bronshtein and Shirokov (in press). Photo: Evgeny Zheltov. 
In 1967, Mitlyanskaya and her colleagues from the Moscow Research Institute for Art Industry (MRIAI), Irina Karakhan and Ludmila Chubarova, tried to change that situation and give the Uelen artists a historic perspective on Chukchi and Yupik art. For the next 20 years, they regularly visited Chukotka and discussed with local artists, especially those who recently joined the carving workshop, during their long stays in Uelen. They were especially interested in discussing traditional means and tools that Chukchi and Yupik carvers and engravers used for many centuries. They even prepared an album with photographs of Chukotka traditional craft from the largest museum collections. Another album included some photographs of Inuit art from Alaska, Canada and Greenland. "The artists had a great interest in the albums: older carvers uncovered things from their past while the young learned a lot about the art traditions of their people" (Mitlyanskaya 1976: 139).

The involvement of Mitlyanskaya, Karakhan and Chubarova in the preservation of knowledge about the art traditions of the Chukotka Indigenous peoples, has been gaining an ever-increasing importance. In the 1970s there was hardly any "first generation" carvers and engravers in Uelen, and then their pupils, who had joined the workshop in the mid-20th century, began gradually to retire. Furthermore, changes that occurred in the sea mammal hunters' life in the 1970s, like the loss of many key components of their traditional culture, additionally, affected the development of their popular art. In order to preserve the transmission of traditions in Uelen culture and to make its residents uncover the rich variety of their own artistic heritage, MRIAI researchers suggested expanding the workshop's activities by including embroidery. Since reindeer hair embroidery as well as fur and skin applications are traditional forms of Chukchi and Yupik female needlework, many Uelen women, and especially the elderly, were good embroiders. Art craft exhibitions, which were in the 1960s and 1970s quite often organised by art critics from Moscow and Leningrad, displayed Uelen decorative balls, dancing gloves, and wall panels along with ivory carvings, in order to demonstrate the integrity and versatile nature of Chukotka folk art. The inclusion of embroiders in the workshop had a positive impact on the work of carvers and engravers. Warm brown tones that echoed the colour of reindeer fur became dominant in their works in the 1970s. The forgotten tradition to cover the carved polar animals with ornamental engraving revived as well. Thin black patterns on the surface of the carving underlined the whiteness of the walrus tusk, and enhanced its mystery and decorative effect.

\section{The last decade of the 20th century}

The end of the last century was one of the most complex periods in the history of Uelen carving. In early and mid-1980s, the situation was still relatively stable in Uelen as well as in Chukotka at large. Hunters were hunting sea mammals, herders were herding reindeer, and artists were working in the workshops since the Uelen workshop had at that time four branches (in Lavrentiya, Lorino, Inchoun, and Neshkan). But the severe political and economic crisis at the end of the 1980s changed the picture quite dramatically. Delivery of food and industrial goods to the far North almost stopped. 
Gasoline shortage prevented sea mammal hunters to hunt the way they had done it before. Reindeer livestock sharply decreased. Chukotka was near to starving. The economic crisis from the late 1980s to the early 1990s had another sad consequence in Chukotka. Many people started deserting the Arctic: those who had previously migrated from central Russia to Chukotka were the first ones to leave. As many of them were regular buyers of carvings, their departure affected Uelen artists in a quite negative way.

Nevertheless, many Uelen carvers and engravers continued their work. Moreover, they were experimenting new artistic conceptions even in that extremely difficult period. For instance, during the second half of the 1980s, a central place in the walrus tusk patterns was occupied by concentric circles and ovals as well as by continuous and faltering lines (Figure 9). Their geometrical configurations are similar to some prehistoric Eskimo patterns. One of the reasons for their occurrence in Uelen carving at the end of the 20th century was the resuming of archaeological excavations in Uelen's vicinity. The archaeologists of the State Museum of Oriental Art in Moscow who conducted those excavations joined the program of work with the local artists developed by the MRIAI researchers. At the end of every field season, they visited the Uelen workshop and showed their findings. The author of these lines was lucky to witness Uelen artists holding Old Bering Sea harpoon heads and "winged objects," as they carefully studied their design and background with great appreciation for the masterful skills of their makers.

Creative appropriation of the prehistoric Eskimo artistic heritage became important but was not the only direction in the further development of the Uelen craft in the last decades of the 20th century. Many artists from that period have been following the path trodden by the carvers and engravers from the 1950s to the 1970s. One of the most prominent representatives of the traditionalist movement in Uelen ivory carving was Ivan Seigutegin. Both form and content of his group compositions and engravings keep close to the works of early Uelen artists who used narratives about the lives of Arctic sea mammal hunters as their themes (Figure 10).

Traditionalism in carving and engraving in the 1980s and 1990s was caused not only by the influence of the artists' mentors. In many respects it was also due to the ambition of the Uelen workshop leaders to deliver products that are familiar to the buyers. Young carvers and engravers had to work for a while on copying the best known carvings and engraved tusks before getting the opportunity to work independently (Bronshtein and Shirokov in press: 161-167, 170-172, 188). This condition has certainly limited their creative freedom. On the other hand, copying classical masterpieces was an excellent training for the beginners. By studying their predecessors' works, they acquired valuable skills and techniques which they eventually applied to their own original works. 


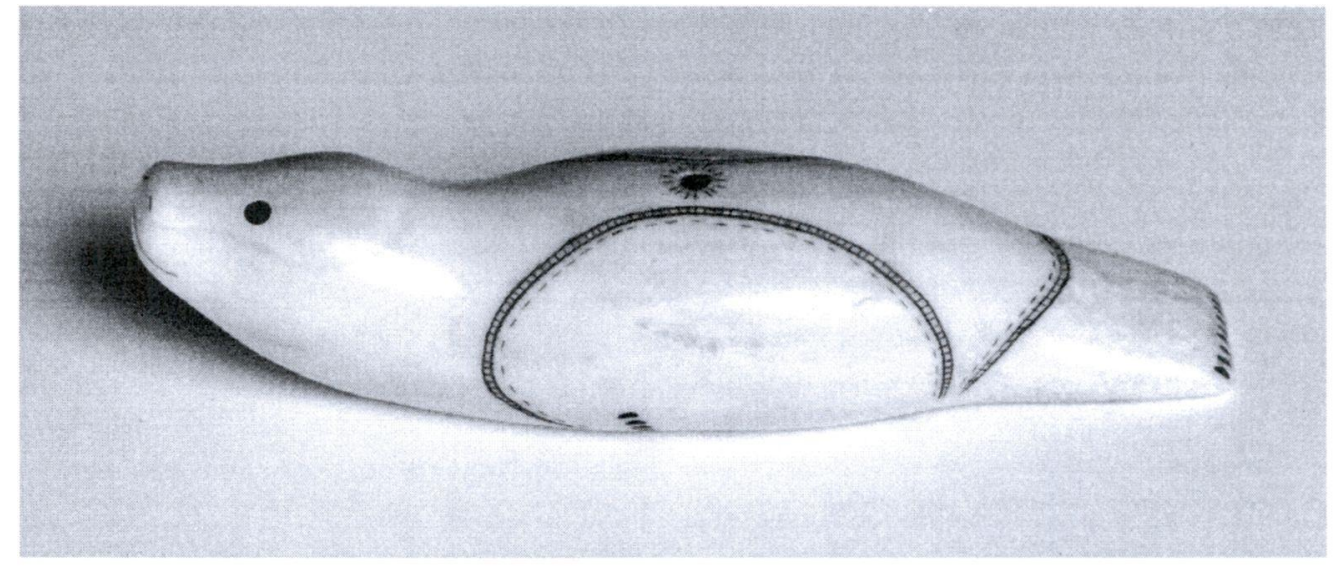

Figure 9. Walrus tusk carving and engraving of a seal by Oleg Kaliach, 1987. Source: Bronshtein and Shirokov (in press). Photo: Evgeny Zheltov.

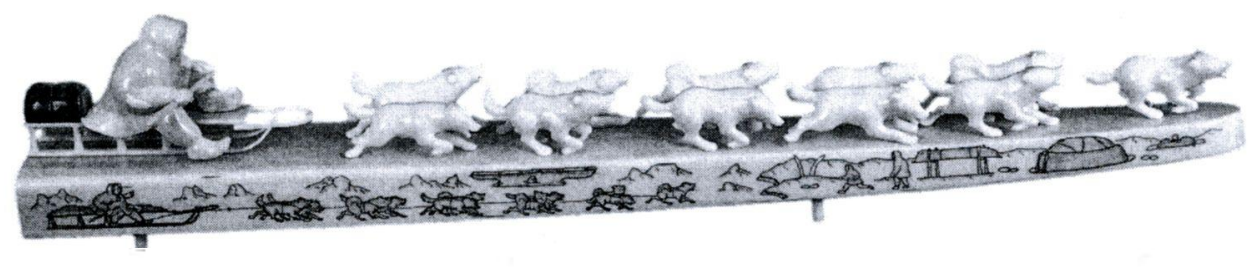

Figure 10. Walrus tusk carving and engraving of a dog sled by Ivan Seigutegin, 1990s. Source: Bronshtein et al. (2002). Photo: Alexey Vakhrushev. 


\section{New century, new problems: the 2000s}

Since the first years of the new 21st century, the economic situation in Chukotka has been changing for the better. Central supply for the northern settlements was not the only improvement. The very basis of the economic life has been changing as market relations have been established and many visitors, including foreign tourists, have started visiting the country. Theses economic and social changes have obviously revived the arts and craft industry in Chukotka. While in the 1990s Uelen was the only centre for Chukchi and Yupik fine arts, today there are at least four such centres. Besides Uelen, there is one in the capital Anadyr and two others in the big settlements of Egvekinot and Bilibino. Still, Uelen has a special place in this list as it keeps close to the traditional Chukchi and Yupik carved and engraved works.

More than 20 artists work today in the Uelen carving workshop. If their number is lower than in the early $1980 \mathrm{~s}$, it is nevertheless significantly higher than in the late 1990s. Uelen artists continue to create carvings, engraved tusks, and jewellery. The traditional images and narratives of their works are completed by some new motifs. They often look for inspiration in the prehistoric Yupik art by reinterpreting its forms. At the beginning of the 21 st century, the Uelen artists' search for new artistic means resulted in a great stylistic variety, including some techniques borrowed from metal engraving that uses brushes and burins when engraving images on a metal plate. The latter technique is in many respects close to the traditional way of drawing on a walrus tusk. In a short time, Uelen engravers made this new technique their own, so that today there are notable engravers among both youngsters (e.g., Stanislav Il'kei) and veterans like Galina Irgutegina (Figures 11 and 12).

The wide variety of Uelen carvings and engravings at the turn of the century reveals two issues. The first one regards the future of coastal Chukchi and Yupik art. The second one informs about the role of Uelen carving in the Indigenous culture of Chukotka. When analysing Uelen contemporary works, one has to acknowledge that along with the masterpieces one can also find a great deal of "art for tourists." Its presence is part of a process that occurs in many places beyond the borders of Chukotka. There is, of course, some positive financial impact on artists' material condition, and this aspect is particularly relevant for Uelen residents today. However, the negative side of this art for tourists is that its expansion may provoke the disappearance of the original art tradition and be substituted by a superficial souvenir production. This would be a dangerous tendency especially since Uelen carving is an extremely significant component of the current Chukchi and Yupik cultures. Nowadays, many traditional features of the Arctic culture, customs and ceremonies are disappearing and Indigenous languages are less spoken than before. In this context, for many of Chukotka Indigenous people art works made of walrus tusk has become one of the noticeable symbols of their ancestral culture. This explains the popularity of the folklore compositions in the ivory and bone carvings and engravings, the Uelen artists' attraction for some prehistoric Eskimo motifs, as well as that amazing devotion to ivory carving that they showed in the otherwise difficult 1990s. 


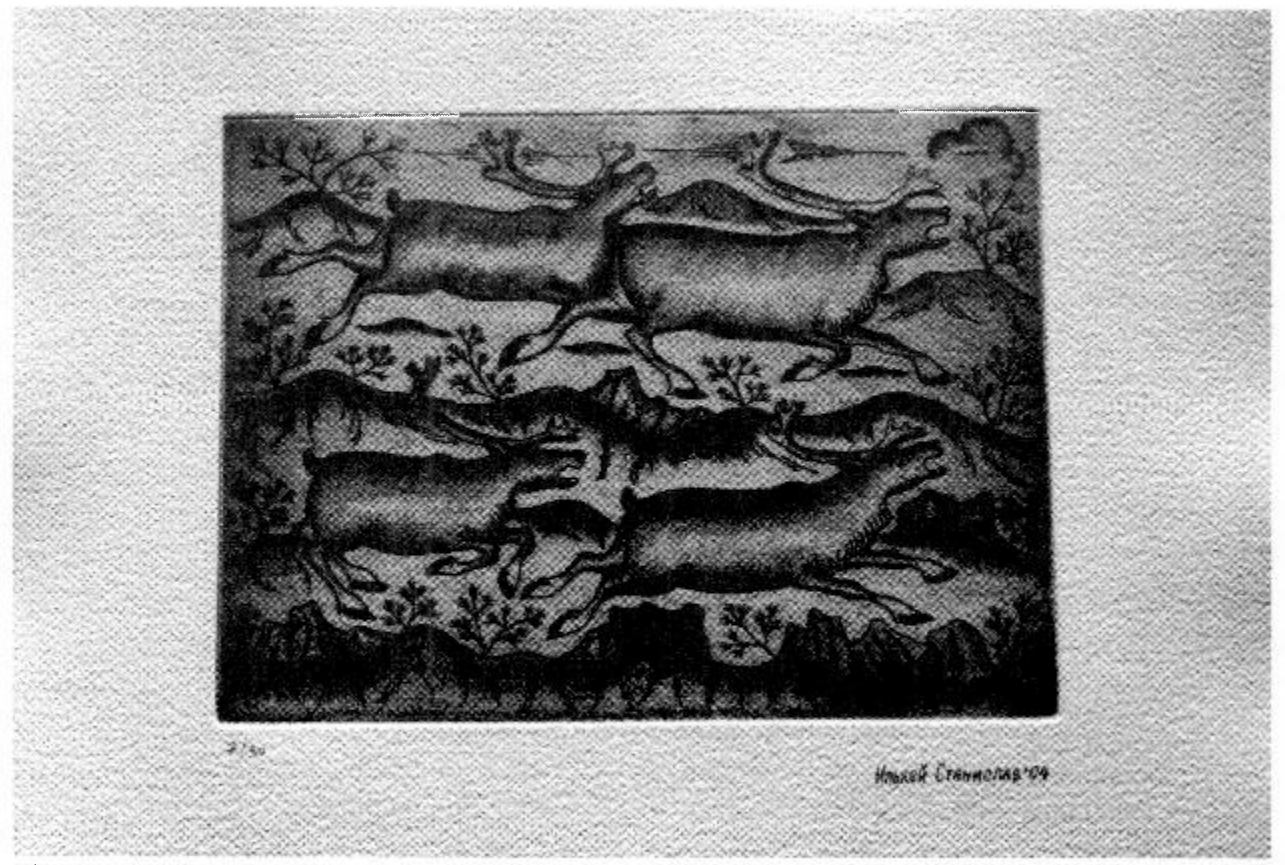

Figure 11 . Woman with a child. Lithography by Galina Irgutegina, 2004. Source: Cerny Inuit Collection. Photo: Maria T. Brito.

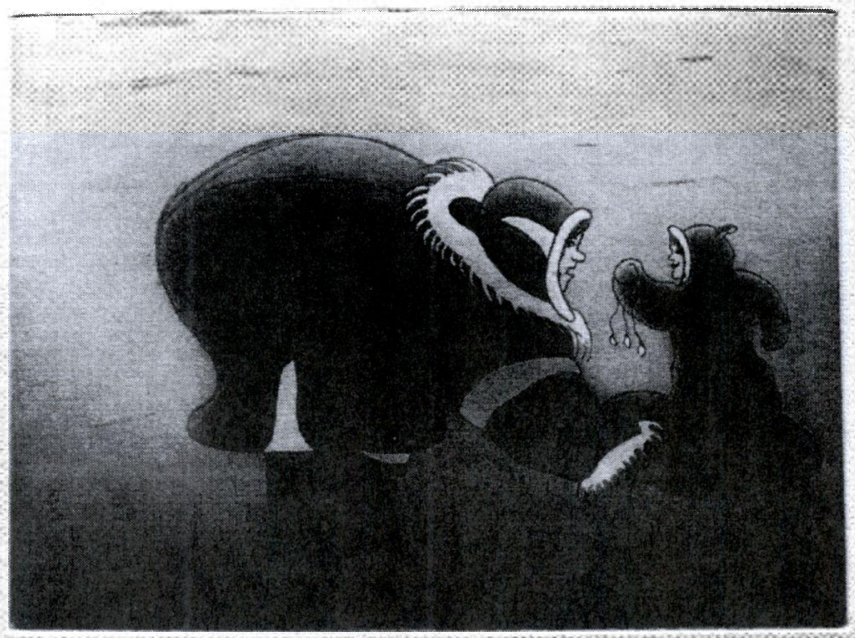

Q35:

Sourcuber when of

Figure 12. Summer. Lithography by Stanislav Il'kei, 2004. Source: Cerny Inuit Collection. Photo: Maria T. Brito. 
It could hardly be exaggerated to say that the future of two millennial cultures, those of the coastal Chukchi and Yupik peoples, relies in many respects on the destiny of the Uelen carvers and engravers. My personal experience with these talented and hardworking people is that in most cases they show the greatest interest towards their people's history and culture. In addition, they are skilful hunters, dancers and storytellers ${ }^{2}$. At the same time they are, as every artist, looking for new ways of expression. This confronts them with a difficult choice. New trends in art, as well as new buyers' expectations, are often in conflict with their original system of values. Hence the current context reorients their creative work towards an art for tourists. There were other periods, such as the end of the 19th century, the 1920s and 1930s, as well the post-war decades, when Uelen ivory carving was a kind of art for tourists. However, there still were some strong art traditions that, judging by the archaeological data, had existed in the extreme northeast of the Chukotka Peninsula in the beginning of our era. It is significant as well that up to the 1950s and 1960s, traditions were strong in the life of the sea mammal hunters in Chukotka. This contributed to the artistic reproduction of some spiritual stereotypes that have, in turn, maintained the continuity in their art. Nowadays in Uelen, it is another story. The transformation of the ivory carving in some art for tourists can radically distort its very essence, and therefore the core of the Chukchi and Yupik spiritual cultures of the 21 st century, as well as their worldview and relation to nature. It is hardly conceivable that such changes would have any positive consequences for the peoples living in the severe climatic and environmental conditions of the Arctic.

What can the scientific community do for the Uelen carvers and engravers? I do not think that today it would be possible or even relevant to send another professional artist in Uelen as it happened in the 1930s and 1950s. A non-resident's constant presence might dampen the local artists' initiative. It might be perceived as a way back to the 1970s and the middle of the 1980s when the workshop was managed by visiting bureaucrats. As for fieldwork, the experience of Tamara Mitlyanskaya and her colleagues might be relevant to the ethnologists. In my view, a most important initiative would be to create some "data-system tradition" in Uelen, some kind of databank about ancient and contemporary Indigenous art in Chukotka. Such a project may start with the periodical publication of booklets and catalogues about Chukchi and Yupik art. Another step in the right direction would be to establish new collections of Chukchi and Yupik carvings to be displayed in Uelen (there is a small museum within the workshop), as well as in other settlements. To some extent this process has already begun since today one can see Uelen carvings, engraved tusks, ornaments and engravings from the 1980s to the 2000s in Chukotka's capital Anadyr (Museum Centre "Chukotka Heritage"), Moscow (State Museum of Oriental Art), and Bern (Cerny Inuit Collection Gallery). Yet this is just the beginning of a long and probably uneasy path.

With the kind permission from the artist and art historian Irina Karakhan, I quote here an excerpt from a letter that Uelen engraver Stanislav Il'kei (who came himself from a family of engravers) sent to her in December 2006: "I shall bring fame to the carving and engraving art of my clan as my mum and my grandfathers Tukai and Vukvol have done it before. I shall fulfil my promise throughout my life so that my ancestors would be proud of me. I believe that they look at me and trust me. I will try to be worthy of their names." 
But the ultimate goal is too important to be afraid of these difficulties. This goal is to support the people who enrich not only the culture of Chukotka, but the culture of the Arctic. Without the original art of the coastal Chukchi and Yupik peoples, a fragment of the all-human cultural mosaic would disappear, a significant polar settlement such as Uelen would lose its unique expression that has been shaped by a 2000 year history of hunters and artists.

\section{References}

ARUTIUNOV, Sergei A. and Dorian A. SERGEEV

2006 Ancient cultures of the Asiatic Eskimos: The Uelen cemetery, translated and edited by Richard L. Bland, Anchorage, U.S. Department of the Interior, National Park Services, Alaska Regional Office (originally published in Russian in 1969).

BRONSHTEIN, Mikhail M., Irina L. KARAKHAN and Jury A. SHIROKOV

2002 Resnaya kosti Uelena. Narodnoie iskusstvo chukotki ('Bone Carving in Uelen. The Folk Art of Chukchi Peninsula'), Moscow, Svyatigor.

BRONSHTEIN, Mikhail M. and Jury A. SHIROKOV

in press Chukotskaya i eskimosskaya reznaya kost'. Khudozestvennye izdelya I-XX vekov iz kollektsii Muzeia Vostoka ('Chukchi and Eskimo ivory carving. Artwork of the 1st to 20th centuries from the North Asia collection of the State Museum of Oriental Art'), Moscow, Media-Complex.

MITLYANSKAYA, Tamara B.

1976 Khudozhniki Chukotki ('Chukotka Artists'), Moscow, Isobrazitel'noe iskusstvo.

1996 Native carvers and outsider artists: Patterns of interaction in Siberian Eskimo/Chukchi ivory carving, Arctic Anthropology, 33(1): 67-88. 